\title{
Effects of bovine subclinical mastitis caused by Corynebacterium spp. on somatic cell count, milk yield and composition by comparing contralateral quarters
}

\author{
Juliano Leonel Gonçalves a , Tiago Tomazi a , Juliana Regina Barreiro a, \\ Daniele Cristine Beuron a, Marcos André Arcari a , Sarah Hwa In Lee ${ }^{b}$, \\ Cristian Marlon de Magalhães Rodrigues Martins a , João Pessoa Araújo Junior c \\ Marcos Veiga dos Santos ${ }^{\text {a,* }}$ \\ a Department of Animal Sciences, School of Veterinary Medicine and Animal Sciences, University of São Paulo (USP), Pirassununga, SP, Brazil \\ ${ }^{b}$ Department of Food Engineering, School of Animal Sciences and Food Engineering, University of São Paulo (USP), Pirassununga, SP, Brazil \\ ' Institute of Biosciences, State University of São Paulo Júlio de Mesquita (UNESP), Botucatu, SP, Brazil
}

\section{A R T I C L E I N F O}

\section{Article history:}

Accepted 6 August 2015

\section{Keywords:}

Corynebacterium spp

Milk composition

Milk yield

Minor pathogens

Somatic cell count

Subclinical mastitis

\begin{abstract}
A B S T R A C T
Subclinical mastitis caused by Corynebacterium spp. (as a group and at the species level) was investigated by evaluating contralateral (healthy and infected) mammary quarters for somatic cell count (SCC), milk yield and composition. Selection of cows with subclinical mastitis caused by Corynebacterium spp. was performed by microbiological culture of composite samples collected from 1242 dairy cows from 21 dairy herds. For each of the selected cows, milk yield was measured and milk samples were collected at the mammary quarter level (i.e., 1140 mammary samples collected from 285 cows) for analysis of milk composition and SCC. The identification of Corynebacterium spp. isolates was performed by 165 rRNA gene sequencing.

One hundred and eighty Corynebacterium spp. isolates were identified, of which 167 (92.77\%) were C. bovis and eight (4.44\%) non-C. bovis; for five of the Corynebacterium spp. isolates (2.77\%), sequencing of 16S rRNA genes did not allow identification at the species level. Mammary quarters infected with Corynebacterium spp. as a group had a higher geometric mean SCC $(197,900$ cells $/ \mathrm{mL})$ than healthy contralateral mammary quarters $(85,800$ cells $/ \mathrm{mL})$. Species of Corynebacterium non-C. bovis were infrequently isolated and did not change SCC, milk yield or milk solid contents when evaluated at the contralateral quarter level. Although $C$. bovis infection showed no effect on milk yield, fat, protein, casein or total solids in milk, it increased SCC and decreased lactose and milk solids non-fat content.
\end{abstract}

(c) 2016 Elsevier Ltd. All rights reserved.

\section{Introduction}

Mastitis is the most costly disease affecting dairy cattle (Djabri et al., 2007; Halasa et al., 2007) and it presents most commonly in the subclinical form caused by bacteria (Djabri et al., 2002; Andersen et al., 2010). Subclinical mastitis increases the somatic cell count (SCC) and reduces the milk yield of dairy cows (Forsbäck et al., 2009). Losses occur due to damage caused by microorganisms to the secretory tissues of the mammary gland and the breakage of cell junctions, which may result in the permanent loss of milk synthesis capacity (Auldist et al., 1995).

Adoption of various strategies to control mastitis during the last few decades has resulted in a decreased frequency of clinical and

\footnotetext{
* Corresponding author. Tel.: +55 1935454240 .

E-mail address: mveiga@usp.br (M.V. dos Santos).
}

subclinical mastitis caused by major pathogens. However, the frequency of subclinical mastitis caused by minor pathogens is still a challenge for dairy farmers (Haltia et al., 2006; Souto et al., 2008; Taponen and Pyorala, 2009). Corynebacterium bovis is a contagious microorganism frequently isolated from cases of subclinical mastitis. Despite the high frequency of isolation, Corynebacterium spp. are considered minor pathogens of mastitis (Bradley and Green, 2005; Schukken et al., 2009). The effects of Corynebacterium spp. on milk yield and composition remain largely unknown.

C. bovis has been described as a commensal of bovine mammary glands (Brooks and Barnum, 1984) and quarters infected with this bacterium may be less susceptible to intramammary infections caused by other mastitis pathogens (Rainard and Poutrel, 1982; Sordillo et al., 1989; Lam et al., 1997; Schukken et al., 1999; Blagitz et al., 2013). It has been reported that $C$. bovis only colonises the teat canal of dairy cows, and as such, it has been used as an indicator of milking hygiene (Watts et al., 2000). C. bovis has however 
also been reported to colonize the teat cistern, gland cistern, and mammary parenchyma (Benites et al., 2003).

Different methods have been used to estimate production losses due to subclinical mastitis in dairy cows. The most commonly used technique is based on the SCC for estimating production losses between herds, among cows, between mammary quarters, or even between identical twin cows (Petrovski et al., 2006; Pearson et al., 2013). The majority of studies have evaluated milk yield and milk composition between healthy and infected mammary quarters based on SCC (Barkema et al., 1997; Wilson et al., 1997; Forsbäck et al., 2010a, 2010b). However, these studies compared the mammary quarters of different cows and this may represent a bias due to heterogeneity between different animals and herds. To the best of our knowledge, no study has reported the effect of subclinical mastitis caused by Corynebacterium spp. on SCC, milk yield and composition by comparing healthy and infected contralateral mammary quarters. This approach could minimize confounding factors at both cow and herd level (such as the cow's immune status at the time of infection, management systems or environmental challenge). Such an experimental design may prove to be more reliable in evaluating the effect of Corynebacterium spp. on SCC, milk quality and yield.

The objectives of the present study were: (1) to determine the effect of subclinical Corynebacterium spp. mastitis as a group and at a species level on milk yield and SCC by evaluating the contralateral (healthy and infected) mammary quarters, and (2) to determine the effect of subclinical mastitis caused by Corynebacterium spp. on concentrations of milk fat, protein, lactose, casein, total solids and solids non fat.

\section{Materials and methods}

Herds and cow selection and sample collection

Twenty-one dairy herds located in the Mid-west area of São Paulo State, Brazil, were enrolled in this study over a 14-month sample collection period. To be enrolled in the study, herds needed to meet the following requirements: (1) good cow identification and recording systems and (2) proper milking management and mastitis control practices (including disposal of first streams of milk, disinfection of teats prior to and after milking using disinfectant solutions, drying teats with disposable towels, and treatment of clinical mastitis cases).

Cows were enrolled in the study based on microbiological cultures performed after the collection of two milk samples. First, composite milk samples (milk from all mammary quarters) were collected aseptically from each cow for screening for Corynebacterium spp. subclinical mastitis following National Mastitis Council guidelines (Oliver et al., 2004). After microbiological culture of the first milk sample, cows with Corynebacterium spp. were individually sampled at the quarter level within 15 days. At the second sample collection, milk yield was measured at the quarter level, and quarter milk samples were collected for microbiological culture and for analyses of composition and SCC.

To determine quarter milk yield and for analyses of composition and SCC, mammary quarters were milked individually using a bucket milking system (Intermaq Milking Systems), which was connected to the milking machine vacuum line. The equipment included a pulsator and a cluster of four liners connected to individual silicone tubing equipped with valves for vacuum release. The system allowed the milk to flow from each mammary quarter to a four-compartment stainless steel bucket. Quarter milk was stirred and weighed, and milk samples $(40 \mathrm{~mL})$ were collected into plastic tubes containing the antimicrobial Bronopol (2-bromo-2-nitropropane-1,3diol) as preservative $(0.05 \mathrm{~g} / 100 \mathrm{~mL}$ milk) according to the International Dairy Federation guidelines (IDF (International Dairy Federation), 1995). Samples were kept refrigerated $\left(4-7{ }^{\circ} \mathrm{C}\right)$ until analysis of composition and SCC

This study (protocol number 2231/2011) was in conformity with the Ethical Principles in Animal Research adopted by the Ethical Committee on the Use of Animals of the School of Veterinary Medicine and Animal Science, at the University of São Paulo.

\section{Microbiological culture procedures}

Microbiological cultures of milk samples were performed according to the National Mastitis Council guidelines (Oliver et al., 2004). Briefly, $10 \mu \mathrm{L}$ of milk was inoculated on blood agar with $5 \%$ defibrinated bovine blood. Inverted plates were incubated aerobically at $37{ }^{\circ} \mathrm{C}$ for $72 \mathrm{~h}$ and observed every $24 \mathrm{~h}$ for colonial characteristics (shape, size, number, and colour), haemolytic ability (presence and type), and possible contamination. Smears were stained by Gram and a catalase test was performed to determine the morphology and differentiation between Corynebacterium spp. genera.

Milk samples with more than two morphologically different colonies were considered contaminated. Briefly, after growth on blood agar, a single small, circular colony (approximately $1 \mathrm{~mm}$ in diameter) with a white-grey or yellowish colour and a slightly raised, dry and/or flaky, non-haemolytic appearance and Gram-positive rods was considered as Corynebacterium spp. Each isolate of Corynebacterium spp. was inoculated in a tube containing $1 \mathrm{~mL}$ of trypticase soy broth (TSB, Becton Dickinson). Tubes were incubated at $37^{\circ} \mathrm{C}$ for $48 \mathrm{~h}$, and centrifuged at $10,000 \mathrm{~g}$ for $10 \mathrm{~min}$. Pellets were washed with $1 \mathrm{~mL}$ of sterile Milli-Q water, centrifuged again under the same conditions, and $1 \mathrm{~mL}$ of TSB containing $10 \%$ glycerol was added, followed by homogenization. A loop from each microtube was streaked on a plate containing tryptic soy agar (TSA, Becton, Dickinson) supplemented with 1\% Tween 80 (Sigma Chemical Company) for confirmation (Watts et al., 2000). Only microtubes containing Corynebacterium spp. were cryopreserved at $-20^{\circ} \mathrm{C}$.

\section{Milk composition and SCC}

Concentrations of milk fat, protein, lactose, casein, total solids and solids nonfat were determined by infrared absorption system using a milk analyser (MilkoScan FT+, Foss Electric). The SCC was determined by flow cytometry using a highcapacity somatic cell counter (Fossomatic FC, Foss Electric).

\section{Corynebacterium spp. subclinical mastitis}

Mammary quarters were considered to have subclinical mastitis when milk samples showed isolation of $>10$ colonies $(1000 \mathrm{cfu} / \mathrm{mL})$ of Corynebacterium spp. (Andersen et al., 2010; Dohoo et al., 2011a, 2011b). Mammary quarters were considered healthy when they had no growth of bacteria within $72 \mathrm{~h}$ incubation of milk from either sampling and an SCC of $<200,000$ cells/mL (Bradley and Green, 2005).

Gene sequencing for identification of Corynebacterium spp.

The isolates were identified genotypically by $16 \mathrm{~S}$ rRNA sequencing analysis as described by Watts et al. (2000). A DNA extraction protocol was performed by adding lysozyme buffer solution, lysozyme $(10 \mathrm{mg} / \mathrm{mL}$; Merck) and resin solution $(10 \mathrm{mg} /$ $\mathrm{mL}$, Chelex100 resin, Bio-Rad Laboratories), heated in a thermocycler at $99{ }^{\circ} \mathrm{C}$ for 10 min (Vaneechoutte et al., 1995). All isolates of Corynebacterium spp. were submitted to amplification with a pair of primers ( $\mathrm{F}-5^{\prime}$ GCGAACGGGTGAGTAACACG3' and R - 5'TCTGCGATTACTAGCGACTCCG3') as described by Huxley et al. (2004). Isolates with no amplification were submitted to a second round of PCR using pairs of primers (F - 5'AGAGTTTGATCCTGGCTCAG3' and R - 5'AAGGAGGTGATCCAGCCGCA3') (Watts et al., 2000).

The second protocol amplification was used to amplify non-C. bovis species. All PCR reactions targeted the $16 \mathrm{~S}$ rRNA gene. After electrophoresis analysis, the purified PCR products were sequenced unidirectionally using the reverse primers. All sequences obtained from the $16 \mathrm{~S}$ rRNA gene sequences were analysed with GenBank ${ }^{1}$ Library Reference online data. Isolates were identified at the species level when their similarities to reference sequences were $\geq 98 \%$ (Watts et al., 2000).

\section{Statistical analysis}

The effects of subclinical mastitis caused by Corynebacterium spp. as a group and at species level on quarter milk yield, composition and SCC were evaluated. The milk yield, composition and SCC of infected quarters were compared with the same variables from healthy contralateral quarters by a strip-plot design by splitting the anterior and posterior mammary quarters in halves. Thus, the left and right contralateral mammary quarters were compared within the half and cow using the following mixed model:

$\mathrm{Y}=\mu+\mathrm{IMI}+\mathrm{Q}+(\mathrm{IMI} \times \mathrm{Q})+\{[\mathrm{C}+\mathrm{C}(\mathrm{H})+(\mathrm{C} \times \mathrm{Q})+[\mathrm{IMI} \times \mathrm{C}(\mathrm{Q})]\}+e$

where $\mathrm{Y}$ is the dependent variable, $\mu$ is the overall mean, IMI and $\mathrm{Q}$ are the fixed effects of variables in that IMI is the presence or absence of subclinical mastitis caused by Corynebacterium spp., and $\mathrm{Q}$ is the contralateral quarters (right or left) within cow; $\mathrm{IMI} \times \mathrm{Q}$ is the interaction between the fixed effects; $\mathrm{C}$ is the random effect of cow, $\mathrm{C}(\mathrm{H})$ is the random effect of cows nested within herd, and $e$ is the random error term.

Somatic cell count at quarter level was converted to linear scores (LS) by the formula (Schukken et al., 2003) and was presented as geometric mean:

LS SCC $=\log _{2}(\mathrm{SCC} / 100)+3$

Statistical models were analysed using the MIXED procedure of SAS version 9.2. Statistical significance was defined at $P<0.05$.

1 See: http://www.ncbi.nlm.nih.gov/nuccore/AF311433.1 (accessed 2 August 2015). 


\section{Results}

\section{Microbiological cultures and sequencing of 16S rRNA genes}

Composite milk samples were collected from 1242 dairy cows during the first sample collection to screen cows with subclinical mastitis caused by Corynebacterium spp. During the second sample collection, milk yield was measured and milk samples were collected at quarter level from all cows $(n=285)$ previously diagnosed with Corynebacterium spp. subclinical mastitis. Thus, milk samples from 1140 mammary quarters were submitted for microbiological culture and milk composition and SCC.

After culture and sequencing of 16S rRNA genes, a total of 180 Corynebacterium spp. isolates were identified at species level (frequency $15.79 \%$ ) and the results have been reported previously (Gonçalves et al., 2014). C. bovis was the most isolated Corynebacterium species ( $n=167 ; 92.78 \%$ ) from subclinical mastitis cases at the quarter level. Eight isolates (4.45\%) were identified as nonC. bovis, namely, C. amycolatum $(n=1)$; C. aquilae $(n=2)$; C. auriscanis $(n=2)$; C. casei $(n=1)$; C. efficiens $(n=1)$; and C. xerosis $(n=1)$. For five Corynebacterium spp. isolates $(2.77 \%)$, sequencing of $16 \mathrm{~S}$ rRNA genes did not allow identification at the species level but the methodology suggested that the isolates could be $C$. xerosis, $C$. freneyi or C. hansenii; and two isolates could be $C$. auriscanis or C. resistens.

\section{SCC, milk yield and composition}

We hypothesized that there is no difference in milk yield and composition between contralateral healthy quarters in the same udder of a cow and so evaluated 60 pairs of contralateral mammary quarters (both healthy) as controls to observe whether milk yield and composition of samples from the same udder were similar when the quarters presented SCC $<200,000$ cells/mL and were culture negative (Table 1). There was no difference in milk yield, composition (fat content, protein, casein, lactose, total solids and solids nonfat) and SCC between healthy contralateral quarters.

Table 1

Milk yield, composition and somatic cell count of pairs of contralateral healthy quarters $(n=60)$.

\begin{tabular}{|c|c|c|c|c|}
\hline \multirow[t]{2}{*}{ Item } & \multicolumn{2}{|c|}{$\begin{array}{c}\text { Contralateral } \\
\text { healthy quarters }\end{array}$} & \multirow[t]{2}{*}{$\mathrm{SEM}^{\mathrm{b}}$} & \multirow[t]{2}{*}{$P$} \\
\hline & Right & Left & & \\
\hline Milk yield ${ }^{c}$ & 1.91 & 1.90 & 102.28 & 0.896 \\
\hline FCM $3.5 \%$ d & 1.95 & 1.95 & 170.47 & 0.819 \\
\hline $\mathrm{SCC}^{\mathrm{e}}$ & 59,760 & 60,410 & 6.77 & 0.945 \\
\hline LS SCC $^{\mathrm{f}}$ & 2.257 & 2.273 & 0.008 & 0.572 \\
\hline \multicolumn{5}{|c|}{ Milk composition (g/kg) } \\
\hline Fat & 37.22 & 36.22 & 1.45 & 0.625 \\
\hline Protein & 31.89 & 31.85 & 0.49 & 0.948 \\
\hline Casein & 24.68 & 24.69 & 0.39 & 0.995 \\
\hline Lactose & 46.19 & 46.11 & 0.24 & 0.822 \\
\hline Total solids ${ }^{g}$ & 124.92 & 123.75 & 1.76 & 0.639 \\
\hline Solids non fat ${ }^{\mathrm{h}}$ & 87.70 & 87.53 & 0.56 & 0.837 \\
\hline \multicolumn{5}{|c|}{ Milk components yield (g/milking/quarter) } \\
\hline Fat & 73.72 & 71.32 & 5.51 & 0.757 \\
\hline Crude protein & 61.66 & 60.42 & 3.52 & 0.803 \\
\hline Casein & 19.74 & 19.40 & 1.20 & 0.844 \\
\hline Lactose & 91.64 & 89.98 & 5.72 & 0.837 \\
\hline Total solids & 245.88 & 240.24 & 15.16 & 0.792 \\
\hline Solids non fat & 172.16 & 168.92 & 10.29 & 0.824 \\
\hline
\end{tabular}

a Mammary contralateral healthy quarters ( $\mathrm{SCC}<200,000$ cells $/ \mathrm{mL}$ with no positive culture).

b Standard error of the mean.

c Quarter milk yield ( $\mathrm{kg}$ ) from a single milking of the day.

d $3.5 \%$ fat-corrected milk yield.

e Average geometric mean somatic cell count (cells/mL).

f Somatic cell count converted to linear scores.
A total of 92 (46 pairs) contralateral mammary quarters were evaluated. Milk yield, composition and SCC from 46 mammary quarters with subclinical mastitis caused by Corynebacterium spp. as a group were compared with contralateral healthy mammary quarters. Quarters with Corynebacterium spp. subclinical mastitis had higher geometric mean SCC $(197,900$ cells $/ \mathrm{mL})$ than the contralateral quarters (85,730 cells $/ \mathrm{mL})$. Quarters with Corynebacterium spp. subclinical mastitis produced less lactose $(45.50 \mathrm{~g} / \mathrm{kg})$ than the contralateral quarters $(45.91 \mathrm{~g} / \mathrm{kg})$. There was no effect $(P>0.05)$ of subclinical mastitis caused by Corynebacterium spp. on milk yield and concentrations of milk fat, protein, casein and total solids. The average milk yield from a single milking was $1.92 \mathrm{~kg}$ for Corynebacterium spp. infected quarters and $1.97 \mathrm{~kg}$ for healthy quarters (Table 2).

After species identification of Corynebacterium spp. isolates, $C$. bovis and non-C. bovis species were separated. Milk yield, composition and SCC from 35 quarters with subclinical mastitis caused by $C$. bovis were compared with the contralateral healthy quarters. As expected, quarters infected with $C$. bovis had higher SCC $(174,280$ cells $/ \mathrm{mL})$ than healthy contralateral quarters $(87,770 \mathrm{cell} / \mathrm{mL})$. However, no effects $(P>0.05)$ of subclinical mastitis caused by $C$. bovis were observed on milk yield or on concentrations of milk fat, protein, casein and total solids. On the other hand, quarters with $C$. bovis subclinical mastitis produced less lactose and solids non-fat $(P<0.05)$ than the contralateral quarters (Table 2).

We combined all non-C. bovis species isolates because a minimum number of isolates was required to allow statistical evaluation at the contralateral quarter level. Therefore, milk yield, composition and SCC from 11 quarters with subclinical mastitis caused by non$C$. bovis species were compared with their contralateral healthy quarters. No effects $(P>0.05)$ of subclinical mastitis caused by nonC. bovis were observed on SCC, milk yield or composition (Table 2).

\section{Discussion}

The aim of this study was to evaluate how subclinical mastitiscausing Corynebacterium spp. affects the SCC, yield, and composition of milk. Subclinical mastitis caused by C. bovis increased SCC and decreased lactose and solids non-fat content when healthy and infected contralateral mammary quarters were compared; however, subclinical mastitis caused by non-C. bovis had no effect on SCC, milk yield or composition.

In general, Corynebacterium spp. and coagulase negative Staphylococci (CNS) are considered minor pathogens causing a mild increase of SCC in response to the intramammary infection. However, both groups have been frequently isolated from cases of subclinical mastitis (Gonçalves et al., 2014; Tomazi et al., 2015). Tomazi et al. (2015) described 11 CNS species causing subclinical intramammary infections. Staphylococcus chromogenes was the species of CNS most frequently isolated from subclinical mastitis cases (74.07\%), and similar to subclinical mastitis caused by $C$. bovis, produced only a mild increase in SCC with no effect on milk yield.

\section{Frequency of Corynebacterium spp. isolates}

Our results indicate a high isolation frequency of Corynebacterium spp. (15.79\%) similar to other studies reporting a high frequency of minor pathogen subclinical mastitis (ranging from $14.6 \%$ to $17.7 \%$ ) (Haltia et al., 2006; Malek dos Reis et al., 2011). Schukken et al. (2009) also found a high isolation frequency of minor pathogens such as C. bovis (5.5\%) and CNS (15\%). A high frequency (14.6\%) of C. bovis in mammary quarters was reported by Haltia et al. (2006), with an SCC of 303,000 cells/mL, which was greater than those found in the present study (174,280 cells/mL). Haltia et al. (2006) reported that the high frequency may be associated with an absence of teat dipping, since only $7 / 25$ farms (28\%) used this procedure. In our 
Table 2

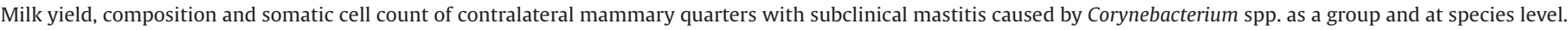

\begin{tabular}{|c|c|c|c|c|c|c|c|c|c|c|c|c|}
\hline \multirow[t]{2}{*}{ Item } & \multicolumn{2}{|c|}{ Corynebacterium spp. } & \multirow[t]{2}{*}{ SEM $^{\mathrm{a}}$} & \multirow[t]{2}{*}{$P$} & \multicolumn{2}{|c|}{ Non-C. bovis } & \multirow[t]{2}{*}{ SEM } & \multirow[t]{2}{*}{$P$} & \multicolumn{2}{|c|}{ C. bovis } & \multirow[t]{2}{*}{ SEM } & \multirow[t]{2}{*}{$P$} \\
\hline & Infected & Healthy & & & Infected & Healthy & & & Infected & Healthy & & \\
\hline$n$ & 46 & 46 & & & 11 & 11 & & & 35 & 35 & & \\
\hline Milk yield ${ }^{\mathrm{b}}$ & 1.92 & 1.97 & 181.44 & 0.595 & 2.18 & 2.28 & 353.90 & 0.753 & 1.85 & 1.89 & 198.61 & 0.663 \\
\hline FCM $3.5 \%$ & 1.95 & 2.00 & 184.35 & 0.598 & 2.22 & 2.31 & 358.20 & 0.753 & 1.88 & 1.92 & 201.45 & 0.664 \\
\hline $\mathrm{SCC}^{\mathrm{d}}$ & 197,900 & 85,730 & 32.04 & 0.011 & 239,680 & 78,970 & 97.50 & 0.259 & 174,280 & 87,770 & 27.69 & 0.015 \\
\hline LS SCC $^{\mathrm{e}}$ & 3.985 & 2.778 & 0.6035 & $<0.01$ & 4.261 & 2.659 & 0.801 & 0.071 & 3.801 & 2.812 & 0.4945 & $<0.01$ \\
\hline \multicolumn{13}{|c|}{ Milk composition $(\mathrm{g} / \mathrm{kg})$} \\
\hline Fat & 34.79 & 34.91 & 1.69 & 0.836 & 32.31 & 33.95 & 2.44 & 0.289 & 35.44 & 35.12 & 1.97 & 0.611 \\
\hline Protein & 32.49 & 32.25 & 0.66 & 0.334 & 32.94 & 31.68 & 0.96 & 0.226 & 32.44 & 32.55 & 0.78 & 0.262 \\
\hline Casein & 25.18 & 24.97 & 0.53 & 0.288 & 25.42 & 24.45 & 0.81 & 0.234 & 25.20 & 25.27 & 0.61 & 0.399 \\
\hline Lactose & 45.50 & 45.91 & 0.39 & 0.006 & 46.43 & 46.71 & 0.71 & 0.255 & 45.33 & 45.75 & 0.43 & 0.019 \\
\hline Total solids & 122.47 & 122.77 & 1.98 & 0.597 & 121.45 & 122.13 & 2.74 & 0.586 & 122.83 & 123.06 & 2.34 & 0.717 \\
\hline Solids non fat & 87.69 & 87.86 & 0.73 & 0.482 & 89.14 & 88.19 & 1.25 & 0.270 & 87.42 & 87.97 & 0.84 & $<0.01$ \\
\hline \multicolumn{13}{|c|}{ Milk components yield (g/milking/quarter) } \\
\hline Fat & 65.51 & 66.71 & 6.12 & 0.730 & 68.77 & 71.62 & 11.20 & 0.768 & 64.81 & 65.77 & 7.06 & 0.794 \\
\hline Protein & 61.55 & 63.46 & 5.43 & 0.541 & 71.80 & 74.17 & 10.81 & 0.808 & 59.12 & 61.05 & 5.98 & 0.514 \\
\hline Casein & 47.75 & 49.24 & 4.23 & 0.537 & 55.60 & 57.51 & 8.42 & 0.800 & 45.95 & 47.44 & 4.66 & 0.515 \\
\hline Lactose & 89.87 & 93.35 & 8.74 & 0.475 & 104.06 & 109.65 & 17.18 & 0.701 & 86.21 & 89.14 & 9.53 & 0.545 \\
\hline Total solids & 235.73 & 242.88 & 21.51 & 0.559 & 266.24 & 277.88 & 41.56 & 0.750 & 228.15 & 234.47 & 24.03 & 0.601 \\
\hline Solids non fat & 170.22 & 176.17 & 15.83 & 0.506 & 197.46 & 206.26 & 31.32 & 0.747 & 163.35 & 168.71 & 17.38 & 0.535 \\
\hline
\end{tabular}

\footnotetext{
a Standard error of the mean.

b Quarter milk yield ( $\mathrm{kg}$ ) from a single milking of the day.

c $3.5 \%$ fat-corrected milk yield.

d Average geometric mean somatic cell count (cells $/ \mathrm{mL}$ ).

e Somatic cell count converted to linear scores.
}

study, the frequency of Corynebacterium spp. was similar to that of Haltia et al. (2006), although all of our dairy farms used teat dipping. The distribution of Corynebacterium spp. was similar to that reported by Huxley et al. (2004) and Watts et al. (2000), which showed a higher frequency of $C$. bovis ( $>75 \%$ ), compared to non-C. bovis species.

\section{Effect of Corynebacterium spp. on SCC}

Composite milk samples from dairy cows were evaluated by Wilson et al. (1997) who described an average of 186,600 cells $/ \mathrm{mL}$ for subclinical mastitis caused by C. bovis and 141,420 cells/mL for subclinical mastitis caused by non-C. bovis. These findings were similar to the results in our study evaluating SCC at the quarter level (Table 2).

Somatic cell count was higher in mammary quarters infected with Corynebacterium spp. than in healthy contralateral quarters and were higher than those reported by Bradley and Green (2005), who found a SCC of between 50,000 and 150,000 cells/mL and by Schepers et al. (1997), who reported an average SCC of 52,500 cells/mL ( $\operatorname{LnSCC} 3.96$ ) for Corynebacterium spp. subclinical mastitis cases at cow and quarter level, respectively. The lower average SCC described by Schepers et al. (1997) was probably due to correcting for SCC (parity, stage of lactation, production level of cows and month of sampling).

At the species level, contralateral mammary quarters had a higher SCC for quarters infected by $C$. bovis than healthy quarters. This result was similar to that described by LeVan et al. (1985) and Ngatia et al. (1991) who reported a higher SCC in mammary quarters infected with C. bovis compared to healthy quarters. Ngatia et al. (1991) reported that quarters infected by $C$. bovis had $<200,000$ cells/mL and were associated with no change in milk production and composition. On the other hand, Coulon et al. (2002) reported that SCC was similar between healthy and C. bovis-infected mammary quarters but they used foremilk samples.

The effect of experimental subclinical mastitis caused by C. bovis was also evaluated by Brooks and Barnum (1984), whose approach differed from the present study in that we evaluated naturally occurring subclinical mastitis. They reported that $C$. bovis-infected quarters had a higher SCC than healthy quarters, similar to our results but the SCC average of infected quarters was $<200,000$ cells $/ \mathrm{mL}$, and the authors suggested that $C$. bovis was an agent that colonises only the teat canal.

\section{Effect of Corynebacterium spp. on milk yield and composition}

Munro et al. (1984) found a decrease in lactose content during the mastitis process; this may occur due to lower lactose synthesis by damaged epithelial cells or the passage of this component of milk to the blood stream. Thus, the lower concentration of lactose in milk could be used as a criterion for mastitis detection (Auldist et al., 1995). In our study there was no decrease in fat and protein, and so the decrease in lactose content contributed to the decrease in solids non-fat content. LeVan et al. (1985) and Coulon et al. (2002) found no effect of subclinical mastitis caused by C. bovis on milk composition, but LeVan et al. (1985) evaluated only protein and fat content.

In the present study, milk yield, composition and SCC from 46 mammary quarters with subclinical mastitis caused by Corynebacterium spp. as a group were compared with the results from contralateral healthy mammary quarters. Quarters with Corynebacterium spp. subclinical mastitis produced less lactose than the contralateral quarters. Because less lactose was produced and there was an increase in SCC, it may be supposed that Corynebacterium spp. does not colonize only the teat canal, as lactose is produced by the alveolar tissue. Benites et al. (2003) isolated Corynebacterium spp. from the teat canal region, the teat cistern, gland cistern, and mammary parenchyma.

Our study shows that there was no effect of subclinical mastitis caused by $C$. bovis on fat content, protein, casein, total solids and milk yield when comparing healthy and infected contralateral quarters. Natzke et al. (1972) found that mammary quarters infected with C. bovis produced less milk than healthy quarters. Other researchers have reported that phosphorus content was lower in a C. bovis infected quarter than in the healthy control (Coulon et al., 2002), and this reinforces the idea that in Corynebacterium spp. subclinical mastitis, breakage of cell junctions may occur and change the permeability of mineral content across the blood-milk barrier. 
Regarding fat and protein content, Brooks and Barnum (1984) reported that there was no difference between mammary quarters experimentally infected by $C$. bovis and healthy quarters. In the present study, we also found no effect of subclinical mastitis caused by $C$. bovis on fat and protein content.

We found no effect of subclinical mastitis caused by nonC. bovis on SCC, milk yield and composition at the contralateral mammary quarter level. We know of no previous studies on the effects of non-C. bovis on milk yield and composition.

Cows were not evaluated for parity, stage of lactation or level of production. Moreover, the milk yield of healthy mammary quarters was assessed from a single milking per day. Therefore, it is estimated that for a cow with a milk yield of $1.9 \mathrm{~kg} /$ quarter/single milking/day would produce around $15.2 \mathrm{~kg}$ of milk/cow/day, over two milkings, and $4636 \mathrm{~kg}$ of milk/lactation of 305 days; these figures are lower than the milk yield of $9610 \mathrm{~kg}$ in 328 days as reported by Schepers et al. (1997).

In general, subclinical mastitis increases the SCC and reduces milk yield of dairy cows (Forsbäck et al., 2009) but this does not seem to be the case for C. bovis as shown by our results. Although C. bovis caused a mild increase in SCC and a decrease in lactose content $(\mathrm{g} / \mathrm{kg})$, the SCC average was $<200,000$ cells $/ \mathrm{mL}$, which is considered a cut-off value for healthy mammary quarters (Malek dos Reis et al., 2011).

\section{Conclusions}

Species of Corynebacterium non-C. bovis are infrequently isolated from cases of subclinical mastitis and did not change SCC, milk yield and milk solid contents when evaluated at the contralateral quarter level. C. bovis was the most frequent Corynebacterium spp. found and had no effect on milk yield, fat, protein, casein, and total solids of milk from dairy cows evaluated at the contralateral quarter level. It did however increase SCC and decrease lactose and milk solids non-fat content.

\section{Conflict of interest statement}

None of the authors has any financial or personal relationships that could inappropriately influence or bias the content of the paper.

\section{Acknowledgments}

We are grateful to the Fundação de Amparo à Pesquisa do Estado de São Paulo (FAPESP), Brazil, for the research funding (2011/142845). We also thank José Garcia Franchini and Lucinéia Mestieri (Qualileite Milk Quality Laboratory, School of Veterinary Medicine and Animal Science - USP, Brazil) for their assistance with laboratory analysis. Preliminary results were presented as an Abstract at the 27th World Buiatrics Congress, Lisbon, Portugal, 3-8 June 2012.

\section{References}

Andersen, S., Dohoo, I., Olde Riekerink, R., Stryhn, H., 2010. Diagnosing intramammary infections: Evaluating expert opinions on the definition of intramammary infection using conjoint analysis. Journal of Dairy Science 93, 2966-2975.

Auldist, M., Coats, S., Rogers, G., McDowell, G., 1995. Changes in the composition of milk from healthy and mastitic dairy cows during the lactation cycle. Animal Production Science 35, 427-436.

Barkema, H., Schukken, Y., Lam, T., Galligan, D., Beiboer, M., Brand, A., 1997. Estimation of interdependence among quarters of the bovine udder with subclinical mastitis and implications for analysis. Journal of Dairy Science 80, 1592-1599.

Benites, N.R., Melville, P.A., Costa, E.O., 2003. Evaluation of the microbiological status of milk and various structures in mammary glands from naturally infected dairy cows. Tropical Animal Health and Production 35, 301-307.

Blagitz, M.G., Souza, F.N., Santos, B.P., Batista, C.F., Parra, A.C., Azevedo, L.F., Melville, P.A., Benites, N.R., Della Libera, A.M., 2013. Function of milk polymorphonuclear neutrophil leukocytes in bovine mammary glands infected with Corynebacterium bovis. Journal of Dairy Science 96, 3750-3757.

Bradley, A., Green, M., 2005. Use and interpretation of somatic cell count data in dairy cows. In Practice 27, 310-315.
Brooks, B., Barnum, D., 1984. Experimental colonization of the bovine teat duct with Corynebacterium bovis and the effect on milk somatic cell counts. Canadian Journal of Comparative Medicine 48, 141-145.

Coulon, J.-B., Gasqui, P., Barnouin, J., Ollier, A., Pradel, P., Pomiès, D., 2002. Effect of mastitis and related-germ on milk yield and composition during naturallyoccurring udder infections in dairy cows. Animal Research 51, 383-394.

Djabri, B., Bareille, N., Beaudeau, F., Seegers, H., 2002. Quarter milk somatic cell count in infected dairy cows: A meta-analysis. Veterinary Research 33, 335-357.

Djabri, T., Huijps, K., Østerås, O., Hogeveen, H., 2007. Economic effects of bovine mastitis and mastitis management: A review. Veterinary Quarterly 29, 1831.

Dohoo, I., Andersen, S., Dingwell, R., Hand, K, Kelton, D., Leslie, K., Schukken, Y. Godden, S., 2011a. Diagnosing intramammary infections: Comparison of multiple versus single quarter milk samples for the identification of intramammary infections in lactating dairy cows. Journal of Dairy Science 94, 5515-5522.

Dohoo, I.R., Smith, J., Andersen, S., Kelton, D.F., Godden, S., 2011b. Diagnosing intramammary infections: Evaluation of definitions based on a single milk sample. Journal of Dairy Science 94, 250-261.

Forsbäck, L., Lindmark-Månsson, H., Andrén, A., Åkerstedt, M., Svennersten-Sjaunja, K., 2009. Udder quarter milk composition at different levels of somatic cell count in cow composite milk. Animal 3, 710-717.

Forsbäck, L., Lindmark-Månsson, H., Andrén, A., Åkerstedt, M., Andrée, L., Svennersten-Sjaunja, K., 2010a. Day-to-day variation in milk yield and milk composition at the udder-quarter level. Journal of Dairy Science 93, 3569-3577.

Forsbäck, L., Lindmark-Månsson, H., Andrén, A., Svennersten-Sjaunja, K., 2010b. Evaluation of quality changes in udder quarter milk from cows with low-tomoderate somatic cell counts. Animal 4, 617-626.

Gonçalves, J.L., Tomazi, T., Barreiro, J.R., Braga, P.A., Ferreira, C.R., Araújo Junior, J.P., Eberlin, M.N., dos Santos, M.V., 2014. Identification of Corynebacterium spp. isolated from bovine intramammary infections by matrix-assisted laser desorption ionization-time of flight mass spectrometry. Veterinary Microbiology $173,147-151$

Halasa, T., Huijps, K., Osteras, O., Hogeveen, H., 2007. Economic effects of bovine mastitis and mastitis management: A review. The Veterinary Quarterly 29, 18 31.

Haltia, L., Honkanen-Buzalski, T., Spiridonova, I., Olkonen, A., Myllys, V., 2006. A study of bovine mastitis, milking procedures and management practices on 25 Estonian dairy herds. Acta Veterinaria Scandinavica 48, 1-6.

Huxley, J., Helps, C., Bradley, A., 2004. Identification of corynebacterium bovis by endonuclease restriction analysis of the 16S rRNA gene sequence. Journal of Dairy Science 87, 38-45.

IDF (International Dairy Federation), 1995. Enumeration of Somatic Cells. FIL-IDF Standard No. 148A. IDF, Brussels, Belgium.

Lam, T.J., Schukken, Y.H., van Vliet, J.H., Grommers, F.J., Tielen, M.J., Brand, A., 1997. Effect of natural infection with minor pathogens on susceptibility to natural infection with major pathogens in the bovine mammary gland. American Journa of Veterinary Research 58, 17-22.

LeVan, P., Eberhart, R., Kesler, E., 1985. Effects of natural intramammary Corynebacterium bovis infection on milk yield and composition. Journal of Dairy Science 68, 3329-3336.

Malek dos Reis, C., Barreiro, J., Moreno, J., Porcionato, M., Santos, M., 2011. Evaluation of somatic cell count thresholds to detect subclinical mastitis in Gyr cows. Journal of Dairy Science 94, 4406-4412.

Munro, G.L., Grieve, P.A., Kitchen, B.J., 1984. Effects of mastitis on milk yield, milk composition, processing properties and yield and quality of milk products. Australian Journal of Dairy Technology 39, 7-16.

Natzke, R., Everett, R., Guthrie, R., Keown, J., Meek, A., Merrill, W., Roberts, S., Schmidt, G., 1972. Mastitis control program: Effect on milk production. Journal of Dairy Science 55, 1256-1260.

Ngatia, T., Jensen, N., Berg, B., 1991. Changes in the bovine udder quarters naturally infected by Corynebacterium bovis. British Veterinary Journal 147, 463-468.

Oliver, S.P.O., Gonzalez, R.N., Hogan, J.S., Jayarao, B.M., Owens, W.E., 2004. Microbiological procedures for the diagnosis of bovine udder infection and determination of milk quality. In: A Global Organization for Mastitis Control and Milk Quality, Fourth Ed. National Mastitis Council Inc., Verona, WI, USA, pp. 1-40, 44-46.

Pearson, L.J., Williamson, J.H., Turner, S.A., Lacy-Hulbert, S.J., Hillerton, J.E., 2013. Peripartum infection with Streptococcus uberis but not coagulase-negative staphylococci reduced milk production in primiparous cows. Journal of Dairy Science 96, 158-164.

Petrovski, K., Trajcev, M., Buneski, G., 2006. A review of the factors affecting the costs of bovine mastitis: Review article. Journal of the South African Veterinary Association 77, 52-60.

Rainard, P., Poutrel, B., 1982. Dynamics of nonclinical bovine intramammary infections with major and minor pathogens. American Journal of Veterinary Research 43 , 2143-2146.

Schepers, A.J., Lam, T.J., Schukken, Y.H., Wilmink, J.B., Hanekamp, W.J., 1997. Estimation of variance components for somatic cell counts to determine thresholds for uninfected quarters. Journal of Dairy Science 80, 1833-1840.

Schukken, Y.H., Leslie, K.E., Barnum, D.A., Mallard, B.A., Lumsden, J.H., Dick, P.C., Vessie, G.H., Kehrli, M.E., 1999. Experimental Staphylococcus aureus intramammary challenge in late lactation dairy cows: Quarter and cow effects determining the probability of infection. Journal of Dairy Science 82, 2393-2401.

Schukken, Y.H., Wilson, D.J., Welcome, F., Garrison-Tikofsky, L., Gonzalez, R.N., 2003. Monitoring udder health and milk quality using somatic cell counts. Veterinary Research 34, 579-596. 
Schukken, Y.H., González, R.N., Tikofsky, L.L., Schulte, H.F., Santisteban, C.G., Welcome, F.L., Bennett, G.J., Zurakowski, M.J., Zadoks, R.N., 2009. CNS mastitis: Nothing to worry about? Veterinary Microbiology 134, 914.

Sordillo, L., Doymaz, M., Oliver, S., Dermody, J., 1989. Leukocytic infiltration of bovine mammary parenchymal tissue in response to Corynebacterium bovis colonization. Journal of Dairy Science 72, 1045-1051.

Souto, L.I., Minagawa, C.Y., Telles, E.O., Garbuglio, M.A., Amaku, M., Dias, R.A., Sakata, S.T., Benites, N.R., 2008. Relationship between occurrence of mastitis pathogens in dairy cattle herds and raw-milk indicators of hygienic-sanitary quality. Journal of Dairy Research 75, 121-127.

Taponen, S., Pyorala, S., 2009. Coagulase-negative staphylococci as cause of bovine mastitis - not so different from Staphylococcus aureus? Veterinary Microbiology 134, 29-36.
Tomazi, T., Gonçalves, J.L., Barreiro, J.R., Arcari, M.A., Santos, M.V., 2015. Bovine subclinical intramammary infection caused by coagulase-negative staphylococci increases somatic cell count but has no effect on milk yield or composition. Journal of Dairy Science 98, 3071-3078.

Vaneechoutte, M., Riegel, P., De Briel, D., Monteil, H., Verschraegen, G., De Rouck, A., Claeys, G., 1995. Evaluation of the applicability of amplified rDNA-restriction analysis (ARDRA) to identification of species of the genus Corynebacterium. Research in Microbiology 146, 633-641.

Watts, J., Lowery, D., Teel, J., Rossbach, S., 2000. Identification of Corynebacterium bovis and other coryneforms isolated from bovine mammary glands. Journal of Dairy Science 83, 2373-2379.

Wilson, D.J., Gonzalez, R.N., Das, H.H., 1997. Bovine mastitis pathogens in New York and Pennsylvania: Prevalence and effects on somatic cell count and milk production. Journal of Dairy Science 80, 2592-2598. 